\title{
Arms Trade Offsets: What do We Know?
}

\author{
by Jurgen Brauer* and J. Paul Dunne**
}

July 2009

\begin{abstract}
This chapter is a review of our empirical knowledge regarding arms trade offsets. Extant evidence suggests that offset arrangements do not yield net benefits for a country's economic development. As a general rule arms trade offset deals are more costly than off-theshelf arms purchases, create little by way of new or sustainable employment, do not appear to contribute in any substantive way to general economic development, and with very few exceptions do not result in significant technology transfers, not even within the military sector. As of 2009, the United States and the European Union have taken official government positions against offset deals. Nonetheless, arms trade offsets are a flourishing practice.
\end{abstract}

[JEL codes: H56, F13]

Paper prepared for the forthcoming "Handbook on the Political Economy of War" edited by Chris Coyne and published by Edward Elgar.

* Corresponding author. Professor of Economics; James M. Hull College of Business; Augusta State University, Augusta, GA 30904, USA; jbrauer@aug.edu; www.aug.edu/ sbajmb; Fellow, Economists for Peace and Security-US; co-editor, The Economics of Peace and Security Journal www.epsjournal.org.uk

** Professor of Economics; School of Economics; University of the West of England, Frenchay Campus, Room 3D22, Coldharbour Lane, Bristol BS16 1QY, UK; john2.dunne@uwe.ac.uk; http://carecon.org.uk; Chair, Economists for Peace and Security-UK; co-editor, The Economics of Peace and Security Journal www.epsjournal.org.uk 


\section{Introduction}

In September 2002, an international conference on arms trade offsets and economic development was held in Cape Town, South Africa and subsequently an edited collection was produced, drawn from selected conference contributions as well as other solicited papers (Brauer and Dunne, 2004). All contributions represented original work and were peer-reviewed and thoroughly edited before inclusion in the volume. The authors include the sweep of top-notch experts in the field. Their institutional affiliation ranges from university professors to think-tank fellows, consultants in private practice, and personnel at defense institutes and defense academies. The geographic origin or current location of the authors spans all continents. Likewise, the case studies include countries from across the globe. In alphabetical order they are: Argentina, Australia, Belgium, Brazil, Denmark, Finland, Germany, India, Indonesia, Japan, the Netherlands, New Zealand, Norway, Poland, Singapore, South Africa, South Korea, Sweden, Taiwan, the United Kingdom, and the United States. The volume was published by Routledge in 2004. This chapter is our summary of the state-of-the-art as reflected in the book's chapters, supplemented by an updated literature search and review (through to July 2009) and by a discussion of emerging issues and policy recommendations.

Although both topics are treated in the book, we do not review here the theory of offsets nor the theory of the economic consequences of offsets. The literature search for $2004-2009$ did not yield new empirical papers on arms trade offsets. We are aware of some work being conducted in East and Central Europe and of isolated interest in the topic in India and elsewhere but to our knowledge there has been no readily accessible, peer-reviewed literature in English since the chapters we commissioned for our 2004 book were published. This book still appears to be the latest word on the subject matter. In terms of policy, however, both the United States and the European Union now officially declare offset deals to be undesirable; this is explained and explored in the main text. The next section considers the nature of offsets, followed by a section discussing the mechanics of offset deals and then one reviewing the evidence of their impact on both sellers and procurers, before concluding with a discussion of the issues involved and lessons to be learned. Where we make use of references to our book, we cite them as (author, page), e.g., (Markusen, p. 81), so that readers are enabled to look up specific details in the book.

\section{What are offsets?}

\section{Definition}

The very definition of what offsets are is disputed. Nonetheless, the main idea is this: ordinarily, a country that wishes to spend, say, $\$ 100$ million to import arms from another country transfers $\$ 100$ million worth of funds to the arms seller, the only value gained in return being the putative national security-value of the imported arms. ${ }^{1}$ To increase the exchange value, the importing country may stipulate that the arms exporting country or firm must take some portion of its $\$ 100$ million revenue to set up arms co-production facilities in the arms importing country, or else to commit itself to any of a variety of other possible activities that would secure a flow-back of some or all of the $\$ 100$ million to the arms purchasing country. If this flow-back is made part of 
the arms trade contract, we call this an offset. The advertised benefit is that the importing country obtains not only the arms but that some of the public funds expended on the arms purchase "remain" in the country and are thus expected to stimulate domestic economic development, just as if they had been spent domestically in the first place.

\section{Motivation}

To be able to double-dip - to get the arms and yet to keep the money at home - is seductive for politicians, especially in democracies, who must justify expenditure of public funds, usually in the face of crying social need. The logic sounds so convincing: sign a contract that requires the arms selling party to use some or all of the expended funds to set up arms production facilities in the purchasing country or to make nonmilitary purchases in or from the arms acquiring country that otherwise would not have been made. In the post-cold war buyers' market, buyers have the upper hand and can extract substantial rents and benefits. Offset demands have therefore become universal.

\section{Magnitude}

The use of offsets is by no means restricted to the field of arms trade. Offsets, and related forms of countertrade, constitute a vast, pervasive business practice involving tens of thousands of people around the globe, reaching far beyond the market for military-related items. The size of the trade is variously estimated at ranging between 5 and 30 percent of world trade. However, governments and international organizations do not track the value of offset trade separately. All estimates offered in the literature and press are guesses and it is by no means clear how they are arrived at.

With regard to the arms trade, some countries do undertake efforts to track the value of offsets, especially the United States where legislation mandates offsets tracking and an annual report to Congress. ${ }^{2}$ The implementing agency is the Bureau of Industry and Security (BIS) within the Department of Commerce. The thirteenth annual report was issued in December 2008 and covers the 15-year span from 1993 to 2007. ${ }^{3}$ For example, for 2007 alone, total U.S. defense-related merchandise exports were $\$ 16.7$ billion of which contracts to the value of $\$ 6.7$ billion came with an offset obligation agreement (ca. 40\%). The value of the agreements amounted to $\$ 5.4$ billion (ca. 80\%). Thus, for 2007 the value of agreements over total exports was $\$ 5.4 / \$ 16.7$ billion, or 32.3 percent.

For this entire 1993-2007 time period, BIS reports 9,249 arms trade offset transactions (rather than agreements, promises which may or may not be fulfilled in future), affecting 53 companies and 48 countries for an actual transactions value of $\$ 45.73$ billion and an offsets value of $\$ 53.61$ billion. The offsets value is higher than the actual value because of the use of multipliers whereby an actual value is multiplied to count toward offset obligation (usually if it is in a preferred industry/product group, as explained below). In this case, the ratio of 53.61/45.73 implies an average multiplier of 1.17. Actual transaction values have been on the order of about $\$ 2$ billion a year with a marked rise toward $\$ 4-\$ 5$ billion in the 2000s (see Figure 1). On average, across all the years covered, U.S. defense exports with an offset obligation make up about 40 percent of all defense export sales and of those, offsets values are the order of 70 percent of the arms contract value.

If one makes the assumption that the United States accounts for one-third of the world arms 
Figure 1: U.S. offset contracts, agreements, transactions,

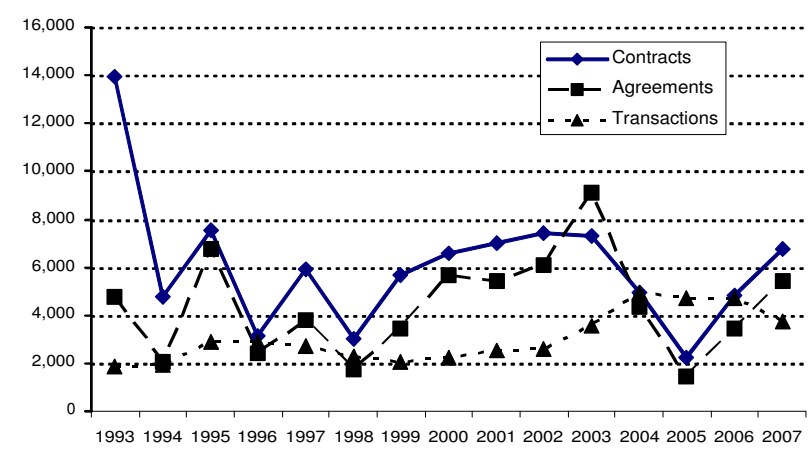

trade (Brauer, 2007, p. 979 based on a 55year record of SIPRI arms transfer values data) and that importing countries' average offset demands are reflected in what they demand from the United States then an initial guess at the dollar value of worldwide offset transactions values would run to about $\$ 135$ billion (3 x $\$ 45$ billion) over this 15-year period, or about $\$ 9$ billion per year. However, the sum of offsets agreements (transactions to be fulfilled in future) was about $\$ 65$ billion

for the United States (BIS, 2008, p. 4, Table 3-1); thrice that would be $\$ 195$ billion worldwide, or about $\$ 13$ billion per year, a not insubstantial sum. ${ }^{4}$ Because agreements include an offsets multiplier, the $\$ 13$ billion needs to be "discounted" accordingly. If one uses the 1993-2007 average of 1.17 for the United States, one arrives at about \$11 billion of worldwide annual offset agreements resulting in future actual offset transaction values, still an appreciable sum.

\section{Countries' objectives and strategies}

Arms importing countries' offset objectives do, of course, evolve over time and their strategies change as their objectives evolve. Some states target certain arms niches that they wish to learn to master for themselves and they structure arms import acquisition and offset demands toward the fulfillment of this goal (e.g., Singapore, Taiwan). Other countries have well-developed specialized arms production niches and use arms trade offsets to assist them to maintain international competitiveness in that niche. Their objective has evolved from vaguely promoting general economic development to the development and maintenance of specific arms-production competences (e.g., Sweden, the Netherlands). Still other countries (e.g., Brazil, India, Indonesia) appear driven by regional power ambitions that would dictate the development of an indigenous ability to produce a sweeping plate of weapon systems in-country, and they therefore pursued or pursue an arms sourcing and offset strategy with broad technology transfer requirements. Yet other states (e.g., South Korea) seek an ability to produce a wide spectrum of systems not because of regional power ambitions but because of a general desire and increasing ability to broadly participate in all industrial markets. Still other states appear to view arms offsets as an opportunity to revive a collapsed or failed indigenous arms industry (e.g., Poland). Other states (e.g., the United Kingdom) view offsets as a tool toward reaching an ever more advanced state of a globally integrated arms manufacturing system in which producers residing in various states produce components for sometimes this and sometimes that lead-manufacturer. The primary objective is joint production parceled out to competitive, cost-minimizing producers across the globe (Mawdsley and Brzoska, p. 106), and offsets can help states to position themselves at the top of the arms supply chain. And still other countries appear to more naively view arms offsets as a way to simply get the arms and keep the money at home as well (as for example South Africa did). ${ }^{5}$ 


\section{Offset characteristics}

While countries' offset objectives are codified in arms offset policies that naturally vary among states and vary within states over time, a set of universal characteristics that define countries' offset arrangements in practice can be discerned. These characteristics include: (1) that importing countries generally mandate offset requirements by law, often to 100 percent of the arms contract value; (2) that offset requirements start at some minimum contract value, often as low as $\$ 5$ million; (3) that multipliers are frequently attached to offset deals, meaning that a specific transaction value (say, $\$ 10$ million) can be multiplied to count toward a higher value (say, $\$ 15$ million) in fulfillment of the offset obligation; (4) that virtually all arms trade contracts now contain clauses that subject arms exporters to a variety of penalties for nonfulfillment of offset obligations (e.g., exclusion from consideration for future contracts). In addition, there are expectations (5) that offsets will reduce arms acquisition costs; (6) that job creation and generalized economic development will result in the arms acquiring country; (7) that the offset will result in new and sustainable work (i.e., that the offset not merely replace work that would have been sourced in-country anyway and that it not be one-off but continuous work); and (8) that the offsets result in general and specific technology transfers since technology is seen as a key component of future economic prosperity.

Elements crucially missing in these offset characteristics are offset contract monitoring, auditing, and feedback to the importing country's defense contract-issuing organization and a plain economic valuation of whether or not the stated military and economic objectives associated with offsets have been met. Tellingly, very few countries have ever carried out even a single formal and independent offset-contract audit to determine to what degree, if any, the hopes with which offset contracts are invested come to fruition.

\section{The mechanics}

\section{Offset mandates}

As a rule, importing countries mandate offsets formally or informally, frequently to 100 percent of the arms contract value. For example, the United Kingdom typically asks for 100 percent (Mawdsley and Brzoska, p. 107). Likewise, Germany typically asks for 100 percent offset both during its rearmament period as well as today (p. 110). The Nordic countries (Denmark, Finland, Norway, Sweden) all have minimum contract values at which 100 percent offsets are demanded (Hagelin, p. 138).

Some countries ask and receive (promises) for more than 100 percent offsets. For example, when Poland signed an aircraft deal with an American company valued at $\$ 3.5$ billion offsets were to amount to a value of $\$ 5.5$ billion (Markowski and Hall, p. 172; 181; the U.S. values these offsets even higher). In one spectacular deal, South Africa is supposed to receive offsets valued at several times the value of the underlying arms import contract. Under a new EU offsets code of conduct, effective 1 July 2009, participating states agree to place a cap of 100 percent on offsets (more on the EU code later on in the chapter). But other countries ask for less than 100 percent offsets. Ordinarily, this happens in small economies whose industrial structure may have difficulty absorbing huge offset deals. For example, for contracts beyond about $\$ 13$ million, Denmark's offset demands drop to 30 percent on the recognition that Denmark cannot absorb 
large offset programs (Hagelin, p. 139). In fact, offset demands can drop to zero, as in the case of Finland and Norway (Hagelin, p. 143). In Taiwan, in contracts above \$50 million, "the government seeks between 30 to 60 percent in offsets" (Chinworth, p. 245). For a time, Australia asked for only 30 percent offsets on contracts valued at A $\$ 2.5$ million or above (Markowski and Hall, p. 272). Similarly, New Zealand generally asks for around 30 percent (Markowski and Hall, p. 275).

Most countries have formal offset laws, policies, or regulations. There are exceptions, however. These include for example Germany (Mawdsley and Brzoska, p. 108), India (Baskaran, p. 217), and Japan (Chinworth, p. 237). In these cases, there nonetheless exist well-understood informal offset policies. Germany for instance effectively runs a procurement cartel to which foreign suppliers gain access only by joining a German-led consortium such that foreign-sourced items are channeled via German (co)production. Singapore, likewise, has no formal offsets policy but channels most contracts through a special corporation set up to deal with arms production issues (Bitzinger, p. 262).

During the 1990s, a number of countries shifted emphasis from a lofty general economic development goal to more narrowly conceived objectives, seeking special technology transfer assistance via offsets for their own military equipment production. These countries include for example all of the Nordic countries (Hagelin, p. 143; Sköns, p. 152). Poland's recent aircraft and armored vehicle deals are specifically tied to a hoped-for reinvigoration of its moribund postCommunist arms production industry (Markowski and Hall, chapter 12).

If not specifically tied to military industry, many countries focus their offset efforts on technology transfers tied to local industry (military or otherwise). This would include for instance Taiwan, Australia, and New Zealand. Only a few countries now, such as South Africa, still seem to believe that offsets can result in across-the-board generalized economic development and job creation.

\section{Minimum offset-contract values}

Countries recognize that offset administration involves fixed and marginal costs. They therefore stipulate minimum arms contract values at which offset requirements kick in. For example, in Denmark foreign-sourced military contracts up to about $\$ 3$ million are offset free; beyond that offset requirements are applied (Hagelin, p. 139). In the United Kingdom, the minimum value is set at $£ 10$ million ( $£ 50$ million for France and Germany under a reciprocal waiver agreement) although Britain automatically asks for offsets on any deal, regardless of the amount, involving the United States (Mawdsley and Brzoska, p. 106). For Poland, the minimum at which 100 percent offsets are demanded is set at contracts valued above $\$ 5$ million of which at least half must benefit the defense industry (Markowski and Hall, p. 179). In Brazil, offsets are asked for contracts over $\$ 1$ million, and 100 percent offsets for contracts over \$5 million (Perlo-Freeman, p. 192). South Korea, "applies offset requirements for any defense transaction in excess of $\$ 10$ million. The minimum required offset is 30 percent, "but has been raised to 70 percent for some recent, high-profile programs" (Chinworth, p. 241). Taiwan "seeks between 30 to 60 percent in offsets in arms sales above $\$ 50$ million" (Chinworth, p. 243). And in South Africa contracts above US\$50 million are "subject to a fifty percent offset or industrial participation policy" (Haines, p. 302). ${ }^{6}$

\section{Multipliers}


Many countries apply multipliers to offset fulfillment. This means that if an arms exporter invests say $\$ 50$ million in an activity that is particularly desired by the importing country (often some form of technology transfer), the $\$ 50$ million may be counted at some multiple toward offset fulfillment. This multiple can range from some very small number such as 0.1 (that is, an extra 10 percent) to numbers as large as 5, 6, or even higher. In the Nordic countries, the size of multipliers is falling: in Finland from 20+ to now as low as 0.5; in Denmark no multipliers are offered at all except for high tech cases; Sweden's maximum multiplier is three but is restricted to limited cases; Norway's maximum is five and goes as low as 0.1 (Hagelin, p. 140). Poland uses multipliers of 0.5 to 2 and exceptionally of up to 5 (Markowski and Hall, p. 179). New Zealand uses multipliers between one and three (Markowski and Hall, p. 275). Like Denmark, the United Kingdom offers no multipliers at all. Moreover, offsets are credited to the arms seller only when transferred technology is actually used by a U.K. firm (Mawdsley and Brzoska, p. 107).

All-in-all, we gain the impression that the size of multipliers has been falling over the decades. For the United States for 1993-2007 offset multipliers applied to only 12.4 percent of arms offset contracts (1,145/9,249 contracts). In the other 87.6 percent, U.S. arms exporters had to deliver the full offset value. For the same time period, in value terms - i.e., offset credit value over transaction value - the average multiplier amounts to about 17 percent. As smaller contract and value numbers imply that more actual offset value must be delivered, this means that buying states play a relatively strong hand against U.S. arms exporters. ${ }^{7}$

\section{Penalties}

Arms offset contracts routinely contain clauses that subject arms exporters to a variety of penalties for nonfulfillment of offset obligations such as exclusion from consideration for future contracts in the country or cash penalties. (Enforcement of course is an entirely different matter.) Norway for instance imposes a penalty of not less than 10 percent of the contract value ${ }^{8}$ and Denmark simply blacklists or bans the supplier (Hagelin, p. 141), as does South Korea (Chinworth, p. 241). In Poland, the offset provider may be held liable for "liquidated damages equivalent to 100 percent of the outstanding offsets obligation" (Markowski and Hall, p. 179). But in practice, Markowski and Hall write (p. 182), "liquidated damages are set initially at 4 percent for four years - not 100 percent as required under the Act - and subsequently at 3 percent." Likewise, Australia and New Zealand use liquidated damages as their penalty option (Markowski and Hall, p. 272; 275).

\section{The evidence}

\section{Cost reduction?}

In the political and news media arenas, the expectation is that offsets will reduce arms procurement costs to the importing country; and certainly that there be no cost premium as compared to off-the-shelf arms purchases. Australia for instance has an explicit "no cost premium" expectation (Markowski and Hall, p. 272). But this is illusionary. The administrative cost of offsets alone is believed to cost arms sellers anywhere from 7 to 10 percent of contract value (Markusen, p. 71), and this cost must be recovered in some form. 
In practice, many countries recognize and pay for the additional cost. For example, Germany asked for 100 percent offsets during its rearmament period and additional costs were accepted if this led to technology transfers, i.e., long-term gains (Mawdsley and Brzoska, p. 110). When several European nations bought F-16 aircraft from General Dynamics in 1975 they paid an extra 34 percent, an estimate that does "not include the costs of the extra time and delays involved in the F-16 coproduction program compared with a direct buy from the USA (e.g., the costs of running-on old equipment)" (Hartley, p. 130). Even worse, in the context of intra-European collaborative projects, Hartley reports cost premium estimates ranging from 33 to 100 percent for certain collaborative arms acquisition projects (e.g., the Merlin helicopter, the Eurofighter Typhoon) as compared to projections for go-it-alone acquisition (Hartley, p. 119). OCCAR, a four-nation procurement agency (France, Germany, Italy, U.K.), is an attempt to base procurement awards on competition rather than juste retour but its success is to be awaited (Hartley, p. 120), as is that of a yet to be established pan-European Arms Procurement Agency.

Even the U.K.'s participation in the U.S. dominated Joint Strike Fighter (JSF) program is estimated to be 4 percent more expensive than outright purchase. The extra 4 percent will buy access to participation and technology, and a go-it-alone program would cost Britain 60 to 105 percent more (Hartley, p. 123). One risk is that already announced reductions in the number of units to be acquired by the United States will raise unit costs for the United Kingdom and other JSF partner nations (Hartley, p. 126) so that the ultimate cost may be much higher than anticipated.

For the Nordic countries, Hagelin reports that Denmark now acknowledges that offsets result in added costs and Finland estimates 10 to 15 percent added cost per offset contract (Hagelin, p. 143). For Finland and Sweden, Sköns reports that for both mandatory and voluntary offsets costs are higher as compared to off-the-shelf purchases (p. 150). The Finnish F/A-18 Hornet deal added between $\$ 100$ and $\$ 200$ million in contract administration cost alone that the Finnish government agreed to bear. This amounted to 3 to 6 percent of the contract value (Sköns, p. 154). In both Finland and Sweden, part of the motivation to switch from vaguely defined general economic development offsets to purely defense-oriented offsets was not only the difficulty to properly target general offsets but also their associated cost (Sköns, p. 160).

For Belgium, Struys reports offset-related "overcosts" estimated at 20 to 30 percent of imported items (Struys, pp. 166-167). Poland's public procurement law of 1994 aimed at competitive tendering and transparency contains certain crucial exemptions with regard to defense acquisitions so that cost savings are unlikely to be achieved; they cannot, at any rate, be monitored because transparency rules have been undermined for defense acquisitions (Markowski and Hall, pp. 178; 182).

In Brazil, Perlo-Freeman reports that "the sheer size and complexity of major warship projects has given rise to serious cost inflation and delays, unmitigated by export orders" (p. 197) and across all arms acquisition categories he notes "the added cost of such deals compared with off-the-shelf procurement" and that "this was accepted by the government as a necessary price for obtaining technology" (p. 197). This assessment also reflects India's experience where licensed technology programs in tanks, aircraft, and naval vessels "faced delays and cost overruns, and resulted in spectacular failures" (Baskaran, p. 218). In its dealings with western suppliers, such as Britain, France, and Sweden, India tended to make use of credit arrangements "to cover the foreign exchange burden. However, evidence suggests that such arrangements resulted in increased selling prices" (Baskaran, p. 221). Likewise, India's arms relation with Russia and eastern Europe "appears to have resulted in a significant burden on the Indian 
economy" (pp. 223-224).

Regarding South Korea, Chinworth writes that it "would be premature to label the country's policies and experiences as a collective failure, but it also would be generous to characterize them as a success" (p. 243). For Indonesia's civilian aircraft program, based on offset deals, Bitzinger reports that its "apparent success was illusory ... In reality, [it] was a bloated, stateowned white elephant, employing many more workers than it needed and was awash in excess production capacity" (p. 264). For instance, the government poured about $\$ 1$ billion into a particular civilian airliner that eventually failed to received FAA certification and thereby made it impossible to bring the aircraft to market anywhere.

For Australia as well, a form of offsets called Strategic Industry Development Activities (SIDAs) are thought to contain a cost premium (Markowski and Hall, pp. 273-274), although mostly of unspecified and uncertain size. In one case, the Australian Department of Defense "itself calculated that the cost premium paid for local industry participation in assembly of F/A18 aircraft in the late 1980s amounted to 29 percent of the value of the additional work required to be done in Australia (Markowski and Hall, p. 280). The authors note that "industry outcomes associated with offsets have failed to live up to their promise" and they make the important point that mere "compliance with offset requirements should not be interpreted to benefit the defense department and/or the economy at large" (p. 280).

Finally, a South African arms procurement deal with certain European nations was trumpeted to generate some 65,000 new jobs but Dunne and Lamb point out that while "this sounds impressive [it] amounts to a cost of R1.6 million per job and is extremely high, nearly 20 times the average cost per job in South Africa's defense industry" (p. 288). As in the case for other countries, the authors argue that "the arms deal has had a positive effect on South Africa's economy, particularly in defense-related industry - after all, the billions must buy something but there is little evidence that the predicted level of benefits have been or will be reached" ( $p$. 289). In 2000, personnel at the South African ministries of finance and of trade and industry estimated the overall return on the arms deal "to be on the order of 94.5 percent ... [and] that during the duration of the deal, anticipated exports would be in the region of 280 percent of the original purchase price" (Haines, p. 303). But in his case study, Haines finds "substantial hidden costs associated with offsets" (p. 312). For example, substantial state investment in regional infrastructure and other resources would be needed for offsets to work as planned but were not forthcoming for the cases and regions he examined. "Yet this kind of cost is not factored into official assessments of the Strategic Defense Program and the associated offset work" (p. 312).

Suppose country A procures $\$ 1$ billion worth of arms from country B with a 100 percent offset requirement to be fulfilled in the form of arms co-production in country A. Also suppose that there is a 30 percent cost premium. One way to view the cost aspect of offsets then is to say that since country B returns funds to country A, the net external cost to $\mathrm{A}$ is if not zero than certainly smaller as compared to a pure off-the-shelf purchase. ${ }^{9}$ There is thus no question that offsets work in the sense that funds are returned to the importing country, ${ }^{10}$ although it has never yet been shown - and often been questioned (e.g., Brauer, 2002) - just what this foreignexchange saving would amount to. But another view is to observe that country A spent a fiscal total of $\$ 1.3$ billion ultimately to be raised from its taxpayers. The scant evidence we have suggests that the extra $\$ 300$ million - the offset "overcost" - does not buy general economic development, does not buy new and sustainable work, and except for limited, specific cases does not result in appreciable technology transfer. This is explored in the next subsections. 


\section{Generalized economic development?}

Even if offsets result in higher total contract cost this could be justified if general economic development is stimulated, as politicians claim and as the news media repeat. The evidence is mixed, however, with the balance of evidence pointing to adverse experiences. In the United Kingdom for instance, offsets are generally directed at small- and medium-sized enterprises (SMEs) and as a consequence of involvement in the American C-130J Hercules transport aircraft "some UK SMEs are now embedded in the supply chain" (Mawdsley and Brzoska, p. 107). But the objective here centered on getting U.K. companies embedded in supply chains whether or not offsets were offered (in fact, in this particular case direct offsets were very small).

Emphasis on SMEs was also important to Denmark and Finland (Hagelin, p. 139) but with little evidence that this strategy worked. To the contrary, a 1999 Finnish offset audit acknowledged that except for some degree of technology transfer, other anticipated offset gains were not realized (Hagelin, p. 143). This is echoed by Sköns, whose review of offset audits in Finland and Sweden finds mostly negative experiences that led both countries to shift offset objectives from vague, general economic development objectives toward narrowly defined military-industry related offsets (p. 160).

Germany appears to have taken a more practical approach from the start of its rearmament program by locating and tightly integrating military technology and defense production in civilian firms, often in peripheral areas to assist regional economic development. ${ }^{11}$ A similarly focused approach, in this case targeted on certain key industries, has been taken by Taiwan. This differs from Japan and South Korea, both of which have aimed - without success - at selfsufficient production in all defense systems (Chinworth, p. 245). Not unlike Denmark, Belgium, and New Zealand today, Taiwan realized early on that certain "practical obstacles exist that limit the economic impact of offset agreements with Taiwan. Analysts have noted that few companies or research organizations within Taiwan have sufficient capability to manage large military programs" (Chinworth, p. 245). But limiting work directed toward its civilian sector to 15 percent of all offset work "minimizes the multiplier effects of offsets" (Chinworth, pp. 245-246). In Poland, offsets are seen as a way to rebuild its ailing defense industry (Markowski and Hall, p. 172) but whether this succeeds and how many sustainable jobs are to be created remains to be seen. The Poles at least appeared to have learned from other countries' experiences that promises of general economic development will likely go unfulfilled.

Whatever the official rhetoric for public consumption, a number of countries have been clear that their primary purpose with arms trade offset work regards not general economic development but development of the indigenous arms industry, for example Japan, South Korea, Taiwan, and Poland. This is also true of Brazil where "offset policy and practice ... involving licensed production, coproduction, and technology transfer has been pursued not so much for direct economic benefit but to develop Brazil's arms industry to fulfill a certain view of its place in the world" (Perlo-Freeman, p. 199).

As mentioned, countries that did harbor and pursue general economic development appear to have given up on this objective (e.g., the Nordic countries). Nonetheless, some countries still pursue this dream. These include Indonesia and South Africa. The case of Indonesia also illustrates a particular vulnerability. Bitzinger writes: "The 1997-98 Asian financial crisis was the defining event that forced Jakarta to reexamine and ultimately dramatically scale back its ambitious plans for its aerospace industry and instead to greatly downsize its arms industry" (p. 264). South Africa also has yet to learn from the prevailing experience. Its officials sought to link 
offset projects "with other national economic and industrial policy initiatives, such as ... Spatial Development Initiatives and Industrial Development Zones," even though analysts suggested that many of the promised investments were dubious and now seem to have been correct (Dunne and Lamb, p. 288). In his study on regional economic development in South Africa, Haines for instance finds few, if any, positive effects. To the contrary, "the recent arms deal will probably reinforce the current economic situation and existing [regional and other] inequalities in South Africa" (Haines, p. 303).

The lesson is that virtually no evidence exists that general economic development goals are ever achieved via offsets. Germany may be the exception, back in the 1950s.

\section{New and sustainable work?}

Another criterion often expressed by officials is that offsets not merely replace work that would have been sourced in-country anyway and that it not be one-off but continuous work. Mawdsley and Broska for instance write that the United Kingdom requires new work for its defense-related industry, moreover new work that is of equivalent technical quality than would otherwise be bought off-the-shelf. This is to avoid offset in-sourcing of inappropriately low-tech work (p. 106). This resulted from the U.K.'s disagreeable experience with its Boeing AWACS purchase in the 1980s. In that case, the U.K. agreed to 130 percent offset work but little genuinely new work resulted. For instance, Rolls-Royce aircraft engines that Boeing bought for its commercial airlines were counted as offset work - accounting in fact for half of the entire offset obligation even though these civilian airliner engines would have been bought anyway (Hartley, pp. 120121). For examples like these, it is estimated that offset work in developed countries brings in perhaps only 25 to 50 percent genuinely new but not necessarily sustained or sustainable work (Hartley, p. 121).

Mawdsley and Brzoska write that in spite of decades of arms licensing and co-operation with Germany, Argentina received virtually no long-term benefit (p. 114). This underscores Brauer's argument and evidence that a minimum condition for successful indigenous arms production efforts is that existing civilian industry must already exist from which a state may branch out into military-related work (Brauer 1991, 2000). Sköns cites "extremely limited" job and export creation for SMEs on account of Finland's Hornet F/A-18 deal (p. 153). Struys emphasizes that Belgium practices an explicit regional political sharing of offsets among its Flemish, Walloon, and Brussels regions. This contributes to offset-related overcosts since work allocation decisions are made on the basis of a political rather than economic calculus (p. 167). Perlo-Freeman reports that Brazil's anticipated Mirage fighter replacement (on the order of $\$ 700$ million) is not thought likely to result in sustainable work unless unexpected export orders were to come in (p. 195). Indeed, of all of Brazil's extensive indigenous arms production ventures started since the 1930s with various forms of offsets only a single one - Helibras - might be deemed commercially viable (p. 196).

Indonesia's attempt to create an indigenous military and civilian aircraft industry collapsed in the wake of the 1997 financial crisis in East Asia. The main aircraft corporation, IPTN, was forced to restructure and, by 2000 , accumulated a debt of $\$ 570$ million. It also had to lay off "around one-third of its workforce, or 5,000 employees" and anticipates to cut an additional 3,500 jobs in the near future (Bitzinger, p. 264). The most egregious recent job generation claim is that of South Africa. It claimed that its arms offset deal will result in 65,000 new jobs over seven years. To Dunne and Lamb, "this sounds impressive but amounts to a cost of R1.6 million 
per job and is extremely high, nearly 20 times the average cost per job in South Africa's defense industry" (p. 288) and it is "not clear that the companies will be internationally competitive to allow follow-on industrial development to be sustainable" (p. 290). ${ }^{12}$

Once more, the main lesson is that there is virtually no positive and certainly no compelling evidence that offsets create new, let alone sustainable jobs. The mere, but very common, assertion of states and their offsets agencies claiming "success" is not evidence. For example, the United Arab Emirates' (UEA) Offset Program Bureau (OPB) reports in its issue 3, April 2008, newsletter on Nextcare Administrative Services (NAS), a healthcare claims administrator. This is "incorporated in Abu Dhabi as a joint venture between the Alfia Investment Company LLC, a company under the UAE Offset Program umbrella, and the National Investor, a leading UAE investment firm." ${ }^{\prime \prime}$ It is utterly unclear why, in the absence of offsets, a healthcare claims processor could not have been established anyway. Likewise, OPB proudly reports the creation of a new holding company - Tawazun Holding - in October 2007 that promptly bought "Caracal International, the first national arms manufacturer in the United Arab Emirates." Jobs and assets already existed, and the newsletter reader must remain mystified as to the exact nature of the "success" of the offsets program.

\section{Technology transfer}

With regard to general and specific technology transfer directed either toward military or civilian industry the record is also mixed. Military-offsets are considered highly desirable for instance to help maintain the U.K. defense industrial base (Mawdsley and Brzoska, p. 106) but the quality of that transfer must frequently be doubted. With regard to the aforementioned Boeing AWACS deal, Hartley writes that U.K. work on aircraft galleys and on-board toilets was counted as "high technology" (p. 121). During the competition to supply replacement fighter aircraft for the Royal Air Force in the U.K., Lockheed Martin made certain claims in favor of its advanced F-16 aircraft. But Hartley writes that "these claimed benefits are rarely supported with empirical evidence ... for example, reference to the technology benefits of offsets rely on ad hoc examples, such as the transfer of US production and management technology to European co-producers. Rarely is consideration given to assessing the market value of such technology and who pays for these benefits (governments or firms)" (p. 130).

The experience with civilian-oriented technology transfers appears to be worse than the examples with military-offset technology transfers already suggest. This is the reason why all Nordic countries, but especially Sweden, are now primarily interested in technology transfers that support indigenous military industry (Hagelin, p. 139). Sköns adds that while technology transfer and export promotion are "complicated to evaluate" (p. 156) Sweden's experience with civilian offset attempts have been most negative (p. 159).

In contrast, a number of authors report that military-directed technology transfers originating with offset deals are considered successful in some country's own terms, at least in certain cases, for example in the case of Brazil, which as a result of technology transfer strategy ended up with a world leader in the regional, Embraer. This was, however, achieved through massive government investment and subsidy and Brazil is still nowhere near having fully autonomous arms production in any sector.

Likewise for India. Baskaran's assessment is that while there is no question that certain technologies were successfully transferred, "the industry failed to acquire capabilities sufficient to close the technology gap with developed countries and keep pace with technological change in 
weapon systems" (p. 219; also p. 224). A particular problem seemed to be that "technology transfers at the level of whole systems worked less efficiently than at component level as sellers tended to withhold core technologies" (Baskaran, p. 220). This hints at what Chinworth found for the case of Taiwan. He writes that its "efforts to develop indigenous systems in the 1990s resulted in items that remained heavily dependent on imported technology; not all domestic development programs were successful" (p. 246). ${ }^{14}$ A response to or proper anticipation of such experiences explains the relatively more successful cases of Singapore and Germany. With regard to the former, Bitzinger's view is that "Singapore's defense industry appears to be thriving, largely because of its core competencies/niche production business strategy" (p. 264). The available offset work is limited in scope but sustainable, even spilling into the nondefense sector. Tellingly, the requirement rather than consequence of this strategy is its "significant impact on further diminishing the nation's already low attachment to offsets as an industrial policy," and in the case of its participation in the U.S. JSF project the country explicitly rejected the idea of offsets (pp. 265-266). Germany was "unusually successful" with its objective of integrating offsets resulting from post-WW II rearmament but almost certainly not only because of its own careful planning but because of NATO's interest in successfully binding Germany into the alliance (Mawdsley and Brzoska, pp. 108-110). Even so, reflecting its civilian-industrial strengths Germany's defense work today is niche production in the automotive and marine industries (tanks, ships) rather than in aircraft and electronics.

Finally, with regard to South Africa, it must be acknowledged that the country has some indigenous industrial capacity that could be exploited if South African firms were to be integrated into an emerging European or global arms production supply chain (Dunne and Lamb, p. 288). But potential need not and may not translate into actual experience. As regards the nondefense industry, the authors question the offset deal. For instance, they write that "it is not clear whether South Africa is getting state-of-the-art technology in areas of growth, or old technology in areas of overcapacity (e.g., stainless steel)" (Dunne and Lamb, p. 290). In fact, the BIS reports that "anecdotal information obtained from industry suggests that 'cutting edge' or nascent technologies under development in the United States are less likely to be transferred to foreign companies in fulfillment of offset obligations than 'older' technologies" (BIS, 2008, p. 19).

\section{Lessons and issues}

Although for many countries this may reasonably be disputed (Dumas, ch. 1), assume that arms imports are in fact needed for legitimate defense purposes. There is nonetheless a crying need for countries to obtain a much better idea of what works under what circumstances, and what does not work (Taylor, ch. 2, and Markowski and Hall, ch. 3, offer some guidelines). To date, the evidence does not suggest that offsets advance countries' long-term goals. To summarize this evidence, it is now quite clear that offsets do not result in arms acquisition cost reductions, that offsets do not stimulate broad-based civilian economic development, that neither substantial nor sustained job creation occurs, not even within the military sector, that almost no successful technology transfer into the civilian sector is observed, and that only limited technology transfer into the military sector occurs, often over decades and at high cost. Moreover, whatever technology is transferred is quickly outpaced by continuous technology advances in the main developed countries, especially the United States.

These lessons can be drawn in spite of severe data problems (e.g., Baskaran, p. 217, on India; Dunne and Lamb, p. 289, on South Africa; Hagelin, p. 143, on Norway; and Hartley, p. 118, 
generally). But from what data points are available, the general picture can be pieced together. The onus to prove otherwise lies with those who would champion the case of offsets. Regrettably, their case relies on pre-offset assertions, rather than post-offset evidence. As Hartley points out, the incentive is to exaggerate benefits and understate or ignore the costs (p. 121).

The case studies raise several additional issues:

1. Data, access, and audits: As mentioned, the data situation is poor. So is countries' willingness to allow researchers access to offset-related data, even in democracies. This is difficult to justify. Any country ought to be interested whether or not policies work and what their costs are. Where public funds are expended, public accounting is needed. There is no reason to treat the military any different. The press widely reports on offset deals so that there can be no fear about military secrets being revealed. Even for their own internal use, governments ought to want to know what offsets cost their countries. This would improve decision making. From the country case studies it appears that only Australia, Finland, and Sweden have ever carried out official audits of specific arms trade offset contracts (in Finland 1 out of 20 offset deals since 1977; in and Sweden 3 out of 15 since 1983).

Audits need to be done on economic principles, counting all economic costs (Brauer, ch. 4). This would include for instance environmental costs associated with weapon production, the cost of manpower training, special infrastructure construction, and other resource uses to support offset work, as well as the opportunity cost of directing resources to offset rather than other work. All this requires a sophisticated set of monitoring tools and abilities by the relevant state agencies which especially in developing countries may not be readily available. Still, expert consultants could be hired to take at least a partial look at things. Offsets should not be excluded from the planning, execution, and feedback loop.

2. Vulnerabilities: Data apart, the case studies lead to a striking observation: Brazil's arms industry collapsed post-1988 with the end of the Iran-Iraq war; Argentina's vanished, Poland's folded, western Europe's bent, post-1991, following the dissolution of the Soviet bloc; and South Africa's industry faltered post-1994 with the end of apartheid. Unsurprisingly for an industry that thrives on latent and actual conflict, less or less intense conflict lowers demand for its products. It seems absurd then that some countries still intend to build the industry and that offsets are thought (and sought) to promote this. In a declining market, exit not entry has to occur. Thus it is virtually certain that even as developing countries are trying to build arms industries, the industry will decline and some producers be withdrawn from the market, as Argentina and Belgium already all but completely have (for evidence of exit, see Brauer, 2007). Tellingly, where tensions remain - the Indian subcontinent, the Korean peninsula, Taiwan - costly arms industry efforts continue.

Vulnerability stems not only from lack of demand but also from other market forces such as the collapse of Indonesia's arms industry post-1997 in the wake of the East Asian financial crisis illustrates. A third vulnerability comes from the growing technology gap between developed and developing countries. Even if some militarily-relevant technology is transferred, it is illogical to believe that leading countries will voluntarily surrender their technology lead. (Indeed, any truly remarkable advances appear to have come from illegally transferred technologies or from exceedingly costly ones unrelated to any officially sanctioned offsets, e.g., rockets, missiles, nuclear technology.)

3. Military Malthusianism: A fourth vulnerability is compellingly illustrated by Scheetz's case study of Argentina (ch. 14). "Military Malthusianism" arises from a single inescapable fact, namely that the unit-cost of major weapon systems rise faster than government budget 
revenues (geometric against arithmetic series). When even well-developed, industrialized countries such as those of western Europe cannot cope anymore with spiraling unit-costs, it is fantastic to believe that developing states will be able to do so. Even the United States cannot entirely cope with the extraordinary cost in all weapons classes, hence its invitation to select countries from across the globe to join it in the development of its Joint Strike Fighter program.

As a consequence of this military Malthusianism, states are left with four options (Hartley, p. 118): (1) the "equal misery" option in which a state's defense programs are cut across the board; (2) the "defense review" option that would reduce states' defense commitments; (3) the "increased defense budget" option which would come at the expense of non-defense programs or a higher tax-take; and (4) the "increased efficiency" option to obtain economies by globalizing arms production and arms acquisition. Options 1 to 3 have variously been tried or are not feasible. Option 4 would make countries' arms industries mutually dependent, and although that is the current trend, the long-run consequence would be that countries cannot fight when important arms component production sites are located in each others' territories. Military Malthusianism thus raises the tantalizing hope that as unitcosts of weapon systems become unaffordable we might be spending ourselves to peace.

But this will not happen for there is a fifth option, not noted by Hartley. That is that states or other actors will offend, deter, and defend differently. They will, in a word, find substitutes. In fact, this has been going on for some time as the examples of state-sponsored or state-supported terrorism, guerrilla warfare, low-intensity warfare, low-tech warfare, proxy wars, and the use of private military companies illustrate. Military Malthusianism implies that we will see more non-conventional conflict.

4. The strong and the weak: To be sure, there is concern that offsets help create international competitors in the short term. But offsets combined with the vulnerabilities listed in points 2 and 3 create not merely an increasing number of arms producers but an enfeebled number of state-based arms industries, kept alive by an infusion of costly state aid as in Brazil, India, Indonesia, South Africa, South Korea, and other countries. It is not surprising then that a number of arms producing countries turn out to be too weak to survive in the arms market (Brauer, 2007). They become infant industries that never grow up and drain the economies of the mother state. Some of these infants have died (e.g., Argentina); others survive by becoming "orphans," adopted by strong industrial powerhouses that integrate the weak into a global supply-chain (e.g., Singapore, an increasing number of western European countries, and to a lesser extent Taiwan and South Korea). ${ }^{15}$

5. Arms globalization: The most likely of Hartley's four options to be adopted in the short-run at least in the European context - is increased arms internationalization. Gradually, EU members will drift toward a European Arms Procurement Agency with competitively let contracts. ${ }^{16}$ Certain developing countries or countries in the Far East will seek to become part of the supply-chain either with U.S. or EU firms, or both, much as is the case now with the commercial aircraft of Boeing and Airbus. In this case, offsets for major weapon systems would largely disappear, and the defense industry would become just another industry, much like globalized automobile or consumer electronics design, manufacturing, and distribution.

This is not to say that we will see a two-bloc system, the United States against the European Union. The Joint Strike Fighter model, although led by the U.S. already involves several European and non-European partners, and it is not inconceivable that in future the EU will take the lead in other projects, such as armored vehicles. Joining an arms supply chain 
may, at any rate, be the only remaining realistic option for several small, industrialized European and non-European countries (e.g., Australia, Denmark, Finland, Norway, New Zealand, South Korea, Taiwan). As Chinworth writes (p. 247), "typically, offsets have been post-production agreements but increased globalization results in more pre-production agreements that determine work share and technology transfers," most likely based on market competition.

6. Offsets will not disappear but may be in retreat: The United States' government officially regards offsets to be "economically inefficient and trade distorting" (BIS, 2008, p. i). More pointedly, it is concerned about the viability of its defense industrial base when bits of the defense supply chain may be undermined by shipping defense-export work abroad. For example, for 2004-2007, the estimated dollar value of domestic work accruing to defenseexport sales in the U.S. aerospace sector was $\$ 18.4$ billion, half of which was lost (transferred abroad) due to offset contracts (BIS, 2008, p. 17, Table 5-4). Put differently, defense exports do result in a net economic gain to the economy of the United States but only by half as much as would have been the case in the absence of offset agreements. A U.S. government "interagency team was able to conclude that the United States is not alone in its concerns about the use of offsets in defense procurement. Other industrialized nations, which also are major providers of offsets, expressed concerns about the adverse effects of offsets on their sales of defense weapons systems. These provider nations expressed interest in a multinational dialogue to address their concerns. From both providers and demanders of offsets, most nations agree with the United States' view that there is a real cost associated with offsets." 17

Correspondingly, 26 states have subscribed to the European Defense Agency's "Code of Conduct on Offsets," which took effect on 1 July 2009. The Code (1) provides for a bit of transparency (collecting states' basic offset information on a common web site), (2) strives to avoid undue competition by collecting defense work across the member states without distorting offsets, that is, to promote the development of a European Defense Technological and Industrial Base (EDTIB), (3) limits offsets to a cap of 100 percent of contract value, and (4) puts a reporting and monitoring system in place. In an interview the director of EDA's Defence Industry and Market Directorate, Arturo Alfonso-Meirino, acknowledged however, that the Code applies only to its subscribing states and the non-members, i.e., major arms buyers such as India, China, and Middle Eastern states still will demand offsets. ${ }^{18}$ Arms trade offsets thus will not just disappear. Nonetheless, that both the United States and the European Union (through EDA) at the highest government levels steer against the use of arms trade offsets suggests that economic arguments would appear to have carried the day.

\section{Notes}

This chapter is based on a paper first delivered at the 8th Annual Defence Economics and Security Conference, University of the West of England, Bristol, June 2004.

\section{References}

[BIS] Bureau of Industry and Security. 2007. "Offsets in Defense Trade. Thirteenth Study." Washington, D.C.: Bureau of Industry and Security, U.S. Department of Commerce. http://www.bis.doc.gov/defenseindustrialbaseprograms/osies/offsets/default.htm [accessed 13 
July 2009].

Brauer, J. 1991. "Arms Production in Developing Nations: The Relation to Industrial Structure, Industrial Diversification, and Human Capital Formation." Defence Economics, 2(2):165-175.

Brauer, J. 2000. "Potential and Actual Arms Production: Implications for the Arms Trade Debate." Defence and Peace Economics, 11(5):461-480.

Brauer, J. 2002. "The Arms Industry in Developing Nations: History and Post-Cold War Assessment," in J. Brauer and J.P. Dunne (eds.) The Economics of Military Expenditure and Arms Production and Trade in Developing Countries. London: Palgrave.

Brauer, J. 2007. "Arms Industries, Arms Trade, and Developing Countries," chapter 30 (pp. 9731015) in T. Sandler and K. Hartley, eds. Handbook of Defense Economics Vol. 2. Amsterdam: Elsevier.

Brauer, J. and J.P. Dunne, eds. 2004. Arms Trade and Economic Development: Theory, Policy, and Cases in Arms Trade Offsets. London: Routledge.

EDA. 2009. "Code of Conduct on Offsets." Brussels: European Defense Agency. http://www.eda.europa.eu/offsets/ [accessed 16 July 2009].

Matthews, R. 2002. "Saudi Arabia: Defense Offsets and Development," chapter 8 in J. Brauer and J.P. Dunne, eds. The Arms Industry in Developing Nations: History and Post-Cold War Assessment. London: Palgrave.

1. Unless otherwise noted, all dollar-values in this chapter refer to U.S. dollars.

2. Section 309 of the Defense Production Act of 1950, as amended.

3. See http://www.bis.doc.gov/defenseindustrialbaseprograms/osies/offsets/default.htm [accessed 13 July 2009].

4. When the nominal dollar figures are deflated using 2000 as the base-year, the totals are nearly identical to those reported in the text, probably because the year 2000 lies about half-way between 1993 and 2007.

5. On the arms exporting side of the ledger, arms exporters (e.g, in the U.S., U.K, Sweden, and others) almost always see offset requirements as a costly distraction and nuisance (e.g., Mawdsley and Brzoska, p. 106), something that has to be done to win contracts but that they would prefer to be able to avoid.

6. For certain EU states, updated information may be obtained from http://www.eda.europa.eu/offsets/, the European Defense Agency's web page on offsets [accessed 16 July 2009]. The EDA was established on 12 July 2004.

7. Information extracted from BIS (2008).

8. See EDA (2009), then click on "Norway."

9. In practice net external, i.e., foreign-exchange, costs are never zero since domestic coproduction invariably requires at least some imports of weapon system components.

10. In 1996-97 in Australia for example, as a consequence of offset regulations, "87 percent of expenditure on defense logistics was spent in-country, 55 percent of capital equipment was 
sourced locally, and 99 percent of expenditure on capital facilities was spent in-country" (Markowski and Hall, p. 273).

11. Germany does not have pure defense firms; instead defense work is carried out in firms that are primarily civilian (Mawdsley and Brzoska, pp. 108-109).

12. An earlier case study on defense offsets in Saudi Arabia "reveals that instead of a projected 75,000 local jobs, the various programs generated employment in the region of 2,000" (Matthews, 2002).

13. Available via www.offset.ae [accessed 16 July 2009].

14. The Indigenous Fighter Aircraft, for example, ran into cost and quality control problems limiting its production run.

15. "The number of competitors in the world arms market has imploded even though each has somewhat greater access to each others' domestic markets. The competition remains oligopolistic but is more international in scope" (Markusen, p. 81).

16. Whether beyond that there will perhaps lie a genuine EU-wide defense and foreign policy with defense functions turned over to the EU as well is beyond this chapter to discuss.

17. BIS (2008, Appendix F, p. 3).

18. EPICOS newsletter, 4 March 2009, p. 4; available on www.epicos.com [accessed 16 July 2009]. 